TELEIOS: Jurnal Teologi dan Pendidikan Agama Kristen

Sekolah Tinggi Teologi Transformasi Indonesia

ISSN 2798-0642 (Online), 2798-1797 (Print)

Volume 1, Nomor 2, Desember 2021 (117-129)

DOI: 10.53674/teleios.v1i2.38

stttransformasi-indonesia.ac.id/e-journal/index.php/teleios/index

\title{
Dampak Metode Pembelajaran Dari bagi Ketuntasan Belajar Siswa
}

\author{
${ }^{1}$ Franty Faldy Palempung, ${ }^{2}$ Ferry J. N. Sumual \\ ${ }^{1,2}$ Sekolah Tinggi Teologi Transformasi Indonesia \\ ${ }^{1}$ frantypalempung@yahoo.com, ${ }^{2}$ ferrysumual@gmail.com
}

\begin{abstract}
Abstrak:
Tulisan ini secara spesifik memaparkan dampak metode pembelajaran daring bagi ketuntasan belajar siswa. Peristiwa Covid-19 yang terjadi awal tahun 2020 hingga sampai sekarang, masih menyebakan kesulitan bagi semua element. Imbas dari pandemi ini di sektor Pendidikan mengharuskan pembelajaran online dilaksanakan. Akibat dari penerapan pembelajaran daring ini, masih menyebabkan kesulitan bagi sebagai indvidu bahkan institusi karena masih belum lengkapnya pra-sarana dalam kegiatan pembelajara daring. Topik ini ditulis dengan menggunakan metode kualitatif deskriftif dengan pendekatan studi literatur. Hasil pada uraian ini mengemukakan bahwa pengertian ketuntasan belajar menurut Permendikbud adalah pencapaian kompetensi sikap, pengetahuan, dan keterampilan meliputi ketuntasan penguasaan substansi dan ketuntasan belajar dalam konteks kurun waktu belajar. Ketuntasan belajar peserta didik merupakan komponen keluaran yang diperoleh dari hasil suatu proses pembelajaran yang didukung oleh orang tua, guru dan lingkungan. Berhasil tidaknya pembelajaran daring bagi ketuntasan pembelajaran, diperlukan kerja sama semua komponen Pendidikan itu sendiri.
\end{abstract}

Kata Kunci: Pembelajaran, Daring, Guru, Peserta Didik

\begin{abstract}
:
This paper specifically describes the impact of online learning methods on the completion of student learning. The Covid-19 event that occurred in early 2020 until now, still makes it difficult for all elements. The impact of this pandemic in the Education sector requires that online learning be implemented. As a result of the application of online learning in, still causes difficulties for as an individual even an institution because it is still incomplete pre-facilities in the activities of online learners. This topic is written using qualitative methods with a literature study approach. The results in this description suggest that the understanding of the completion of learning according to Permendikbud is the achievement of attitude competence. Knowledge, and skills include the completion of the mastery of substance and the completion of learning in the context of the study period. The completion of learning of learners is a component of the output obtained from the results of a learning process supported by parents, teachers and the environment. The success of online learning for the completion of learning, requires the cooperation of all components of Education itself.
\end{abstract}

Keywords: Oline Learning, Teachers, Learners 


\section{Pendahuluan}

Pada masa kini Indonesia bahkan seluruh dunia tengah menghadapi pandemi besar yakni Covid-19 atau biasa dikenal dengan sebutan Virus Corona yang terjadi di hampir sebagian besar negara di seluruh dunia. ${ }^{1}$ Peristiwa wabah ini telah memaksa seluruh masyarakat diseluruh dunia untuk mengubah gaya hidup mereka yang mengedepankan kebersihan, dan menghindari kebiasaan berkumpul atau acara, demi menghindari penyebaran Covid-19 yang semakin merajalela. ${ }^{2}$ Semua element pun baik dari pemerintah, organisasi atau komunitas maupun setiap warga lokal secara inisiatif melakukan upaya pencegahan penyebaran Virus Corona. ${ }^{3}$

Pandemi Covid-19 berdampak besar terhadap setiap aspek di dunia, salah satu aspek yang terkena dampak besar dari pandemi ini adalah aspek pendidikan yang ada di seluruh dunia. ${ }^{4}$ Pendidikan adalah faktor penentu bertumbuh kembangnya setiap SDM pada masing-masing negara menjadi terhambat karena pandemi ini, dikarenakan kebijakan setiap negara yang memperlakukan Lockdown sehingga kegiatan berkumpul mulai dari pendidikan tingkat PAUD, SD, SMP, SMA bahkan sampai tingkat Pendidikan Tinggi dibatasi bahkan dihentikan oleh pemerintah sebagai salah satu upaya pencegahan penyebaran Virus ini. ${ }^{5}$ Pandemi ini mengubah seluruh tatanan bidang pendidikan yang sebelumnya sudah berlangsung sangat lama dan dipaksa untuk memakai aturan baru yang disediakan oleh pemerintah sendiri.

Kebijakan tersebut diambil oleh pemerintah disetiap negara yang terkena dampak langsung dari pandemi Covid-19 yaitu untuk mencegah virus Corona menyebar lebih luas sehingga mengakibatkan banyak masyarakat yang keselamatanya terancam dan bahkan menyebabkan kematian dalam jumlah yang besar, untuk itu segala upaya dilakukan pemerintah disetiap negara yang terkena dampak besar pandemi Covid-19. ${ }^{6}$ Melalui pandemi yang terjadi disebagian besar negara-negara di dunia membuat seluruh masyarakat di seluruh negara menerapkan gaya hidup yang baru atau new normal yang diwajibkan oleh pemerintah setiap negaranya kepada masing-masing masyarakatnya. Walaupun sempat menerapkan beberapa kebijakan dalam waktu yang sedikit lama seperti Lock Down, Social Distancing, Physical Distancing, Isolasi/karantina. ${ }^{7}$ Pembatasan Sosial Berskala Besar (PSBB) sampai tatanan hidup baru (New Normal) selama masa pandemi Covid-19 dihampir setiap negara. Masyarakat diseluruh dunia kembali bangkit dan melawan pandemi yang ada walaupun ada beberapa

1 Sandra Christina Sahensolar and Simon Simon, "Respon Teologis Terhadap Dampak Pandemik Coronaviruses Disease 2019," Manna Rafflesia 8, no. 1 (2021): 176-195.

${ }^{2}$ Arnaz Anggoro Saputro, Yudi Dwi Saputra, and Guntum Budi Prasetyo, “Analisis Dampak Covid-19 Terhadap Kesadaran Masyarakat Dalam Penerapan Protokol Kesehatan,” Jurnal Porkes 3, no. 2 (2020): 81-92.

${ }^{3}$ Marni Br Karo, "Perilaku Hidup Bersih Dan Sehat (PHBS) Strategi Pencegahan Penyebaran Virus Covid19," Prosiding Seminar Nasional Hardiknas 1, no. 1 (2020): 1-4.

${ }^{4}$ Victor Angsono Huatama and Talizaro Tafonao, "Strategi Pemulihan Psikologi Jemaat Pasca COVID-19 Berdasarkan Kitab Mazmur 55," CHARISTHEO: Jurnal Teologi dan Pendidikan Agama Kristen 1, no. 1 (2021): $1-17$.

${ }^{5}$ Ayu Wulandari and Gusti Ngr Sastra Agustika, "Dramatik Pembelajaran Daring Pada Masa Pandemi Covid-19," Mimbar PGSD Undiksha 8, no. 3 (2020): 515-526.

${ }^{6}$ Widya Sari, Andi Muhammad Rifki, and Mila Karmila, “Analisis Kebijakan Pendidikan Terkait Implementasi Pembelajaran Jarak Jauh Pada Masa Darurat Covid 19,” Jurnal Mappesona 2, no. 2 (2020).

${ }^{7}$ Putu Lantika Permadi and I Made Sudirga, "Problematika Penerapan Sistem Karantina Wilayah Dan PSBB Dalam Penanggulangan Covid-19,” Jurnal Kertha Semaya 8, no. 9 (2020): 1355-1365. 
persyaratan yang diwajibkan untuk menggunakan protokol kesehatan yang ketat agar supaya semua kegiatan sosial dan masyarakat dapat berjalan kembali normal. ${ }^{8}$

Dari sinilah peran teknologi sangat dibutuhkan untuk menunjang keberlangsung kegiatan pendidikan tanpa melanggar aturan baru sehingga membuat tempat dan waktu lebih fleksibel serta efisien. ${ }^{9}$ Melaksanakan kegiatan pendidikan secara Online atau Daring (dalam jaringan) dapat dilakukan kapan saja dan dimana saja, dengan ditunjang oleh alat teknologi yang mendukung serta konektivitas jaringan yang stabil dapat membuat kegiatan pendidikan menjadi lancar terkendali. ${ }^{10}$ Hampir disetiap sekolah saat ini memakai metode pembelajaran berbasis Online atau daring. Namun demikian metode pembelajaran terdapat suatu masalah yakni masih adanya beberapa siswa yang tidak cukup memahami materi pelajaran yang disampaikan lewat daring sehingga beberapa siswa tidak memahami dengan baik materi pelajaran disampaikan. ${ }^{11}$ Hal inilah yang membuat peneliti merasa perlu melakukan penelitian lebih lanjut tentang faktor-faktor apa saja yang mempengaruhi daya serap siswa dalam mengikuti pembelajaran berbasis daring. Untuk mempertajam pembahasan lebih lanjut, maka diajukan tiga pertanyaan penelitian sebagai berikut: Apa itu pembelajaran DARING dan Ketuntasan Pelajaran? Adapun tujuan penelitian ini untuk mengetahui apa itu metode pembelajaran daring dan Ketuntasan pembelajaran. Ruang lingkup penelitian ini dibatasi hanya pada Metode pembelajaran DARING dan dampaknya bagi ketuntasan pelajaran.

\section{Metode Penelitian}

Abdurahman mengemukakan bahwa penelitian itu sebagai upaya atau kegiatan yang bertujuan untuk mencari jawaban yang sebenar-benarnya terhadap suatu kenyataan atau realita yang dipikirkan atau dipermasalahkan untuk memperoleh pengetahuan ilmiah tertentu yang berguna, baik bagi aspek keilmuan maupun bagi aspek kepraktisannya. ${ }^{12}$ Penulisan topik ini menggunakan metode kualitatif dengan pendekatan studi litetatur. Proses dalam menguraikan topik ini dimulai dari mengumpulkan berbagai literatur yang berkaitan pada topik ini. Bukubuku, jurnal dan berbagai berita online sebagai data primer dalam memperoleh data. Setelah itu kerangka kerja yang dilakukan peneliti dimulai dengan membaca, mendeskripsikan, menguraikan secara konferensip dan menarik kesimpulan untuk menemukan pertanyaan penelitian pada topik yang dibahas.

\footnotetext{
${ }^{8}$ Simon Simon et al., "Participation of Religious Leaders in Helping the Success of the Government's COVID-19 Vaccination Program," Evangelikal: Jurnal Teologi Injili dan Pembinaan Warga Jemaat 5, no. 2 (2021): 234-245.

${ }^{9}$ K H Lalu Gede Muhammad Zainuddin Atsani, "Transformasi Media Pembelajaran Pada Masa Pandemi COVID-19,” Al-Hikmah: Jurnal Studi Islam 1, no. 1 (2020): 82-93.

10 Ibid.

11 Asmuni Asmuni, "Problematika Pembelajaran Daring Di Masa Pandemi Covid-19 Dan Solusi Pemecahannya," Jurnal Paedagogy 7, no. 4 (2020): 281-288.

12 Ating Somantri Maman Abdurahman, Sambas Ali Muhidin, Dasar-Dasar Metode Statistika Untuk Penelitian (Bandung: CV Pustaka Setia, 2011).
} 


\section{Hasil dan Pembahasan}

\section{Pengertian Metode Pembelajaran}

Metode pembelajaran adalah cara sistematis dalam bentuk konkret berupa langkahlangkah untuk mengefektifkan pelaksanaan suatu pembelajaran. Pernyataan tersebut diperkuat oleh pendapat Iskandar wassid dan Sunendar bahwa metode pembelajaran adalah cara kerja yang sistematis untuk memudahkan pelaksanaan berbagai kegiatan pembelajaran untuk mencapai tujuan yang diinginkan atau ditentukan. ${ }^{13}$ Oleh Sutikno berpendapat bahwa pengertian metode secara harifiah berarti cara sehingga metode adalah suatu cara atau prosedur yang digunakan untuk mencapai tujuan tertentu. Dapat disimpulkan bahwa metode pembelajaran adalah cara kerja sistematis yang memudahkan pelaksanaan pembelajaran berupa impelementasi spesifik langkah-langkah konkret agar terjadi proses pembelajaran yang efektif mencapai suatu tujuan tertentu seperti perubahan positif pada peserta didik. ${ }^{14}$ Abdurrahman Ginting mengemuakakan metode pembelajaran dapat diartikan cara atau pola yang khas dalam memanfaatkan berbagai prinsip dasar pendidikan serta berbagai teknik dan sumber daya terkait dengan lainnya agar terjadi suatu proses pembelajaran pada diri peserta didik. ${ }^{15}$ Oleh Abu Ahmadi \& Joko Tri Prasetya menyebut metode pembelajaran adalah teknik yang dikuasai pendidik atau guru untuk menyajikan materi pelajaran kepada peserta didik di kelas, baik secar individu maupun kelompok agar materi pelajaran dapat diserap, dipahami dan dimanfaatkan oleh peserta didik dengan baik. ${ }^{16}$ Sedangkan menurut Nur Hamiyah \& Muhammad Jauhar metode adalah sebagai cara untuk mengimplementasikan rencana yang sudah disusun dalam bentuk kegiatan nyata dan praktis untuk mencapai tujuan pembelajaran. ${ }^{17}$ Sofan Amri mengemukakan metode belajar mengajar dapat diartikan sebagai cara-cara yang dilakukan untuk menyampaikan atau menanamkan pengetahuan kepada peserta didik, atau anak melalui sebuah kegiatan belajar mengajar, baik di sekolah, rumah, kampus, pondok dan lain-lain. Komalasari. $^{18}$

\section{Fungsi Metode Pembelajaran}

Sebagai Alat Motivasi Ekstrinsik, sebuah metode pembelajaran yang tepat dapat menjadi motivasi tersendiri bagi siswa atau anak didik untuk mau mengikuti proses pembelajaran dengan baik dan penuh semangat. Motivasi merupak salah satu faktor penting bagi keberhasilan kegiatan belajar mengajar, dengan adanya motivasi siswa dapat terpacu untuk lebih menaruh perhatian terhadap materi yang diberikan dan membantu untuk lebih memahami materi tersebut dengan baik. ${ }^{19}$ Sebagai strategi pembelajaran, strategi pembelajaran adalah sesuatu yang

\footnotetext{
${ }^{13}$ Dadang Sunendar Iskandarwassid and others, "Strategi Pembelajaran Bahasa," Bandung: PT. Remaja Rosdakarya (2008): 56.

${ }^{14}$ Sobry Sutikno, "Pemimpin Dan Kepemimpinan," Lombok: Holistica (2014): 33.

${ }^{15}$ Abdurrahman Ginting, "Esensi Praktis Belajar Dan Pembelajaran (Bandung)," Humaniora 42 (2008): 42.

16 Joko Tri Prasetya and Abu Ahmadi, "Strategi Belajar Mengajar," Bandung: CV (2005): 52.

${ }^{17}$ Nur Hamiyah and Muhammad Jauhar, "Strategi Belajar Mengajar Di Kelas," Jakarta: Prestasi Pustaka 294 (2014): 49.

${ }^{18}$ Kokom Komalasari, “Pembelajaran Kontekstual: Konsep Dan Aplikasi” (2017): 47.

19 Yohanes Joko Saptono, "Motivasi Dan Keberhasilan Belajar Siswa," REGULA FIDEI: Jurnal Pendidikan Agama Kristen 1, no. 1 (2016): 181-204.
} 
mutlak diperlukan dalam proses belajar mengajar. Hal ini dikarenakan adanya perbedaan tingkat intelgensia dan juga kemampuan pemahaman yang berbeda antar anak didik. Gaya belajar yang berbeda-beda juga akan mempengaruhi kondisi penenerimaan terhadap materi yang tidak sama antar anak satu dengan yang lainnya. ${ }^{20}$ Untuk itu diperlukan sebuah metode pembelajaran sebagai strategi yang disesuaikan dengan kondisi setiap kelas atau siswa yang dihadapi. Sebagai alat untuk mencapai tujuan, metode pembelajaran adalah alat atau cara yang dilakukan untuk mencapai tujuan dari kegiatan belajar mengajar itu sendiri. Dengan metode pembelajaran yang tepat, diharapkan tujuan dari pembelajaran itu dapat tercapai dengan baik.

\section{Faktor yang Mempengaruhi Metode Pembelajaran}

Ada banyak factor yang mempengaruhi pembelajaran peserta didik. Diantara factor yang memengaruhi pembelajaran itu, pertama faktor siswa. penyusunan sebuah metode pembelajaran dipengaruhi oleh kondisi siswa yang akan diberikan pembelajaran tersebut, baik itu terkait jenis kelamin, tingkat intelegensia dan kemampuan kognitif lainnya, latar belakang ekonomi, sosial, budayanya dan lain-lain. ${ }^{21}$ Kedua, Faktor Tujuan, tujuan yang ingin dicapai dalam sebuah proses pembelajaran sangat mempengaruhi bagaimana sebuah metode pembelajaran akan disusun. ${ }^{22}$ Ketiga faktor situasi, metode pembelajaran disusun dengan mempertimbangkan situasi yang ada dilapangan. Keempat faktor fasilitas, hal yang juga mempengaruhi penyusunan metode pembelajaran adalah ketersediaan fasilitas belajar mengajar seperti kelas, alat peraga, buku dan sebagainya. ${ }^{23}$ Kelima faktor pendidik, metode pembelajaran yang disusun juga dipengaruhi oleh latar belakang pendidik atau pengajar baik itu latar belakang pendidikannya, sosial budaya, maupun ekonominya. Pendidik yang latar belakang pendidikannya tidak memenuhi standard sebagai seorang pendidik, maka akan berpengaruh pada proses pembelajaran. Demikian juga dengan latar belakang social budaya, seperti pendidik yang berasal dari daerah timur Indonesia, memiliki sikap yang tegas.

\section{Manfaat Pembelajaran Daring}

Sejek teknologi mengalami kemajuan pesat, maka besar kontribusinya bagi mobilitas umat manusia. Hal ini berdampak juga kepada dunia Pendidikan dengan majunya teknologi. Dengan majunya teknologi, maka pembelajaran daring mengambil peran penting dalam keberlangsungan pembelajaran. Dengan pembelajaran daring, tentu dirasa banyak manfaatnya. Manfaat dari pembelajaran daring pertama, kapasitas belajar lebih banyak. Belajar secara daring akan memberi siswa kendali penuh atas pembelajaran mereka dan siswa dapat bekerja dengan kecepatan mereka sendiri. Umumnya siswa bekerja lebih cepat dan memproses informasi dengan kapasitas lebih besar. Inilah mengapa belajar daring dianggap lebih baik dilakukan dalam periode belajar pendek daripada di kelas agar siswa tidak lelah. ${ }^{24}$ Kedua

\footnotetext{
${ }^{20}$ Sri Anitah and others, "Strategi Pembelajaran," Jakarta: Universitas Terbuka (2007).

${ }^{21}$ Naeklan Simbolon, "Faktor-Faktor Yang Mempengaruhi Minat Belajar Peserta Didik," Elementary School Journal Pgsd Fip Unimed 1, no. 2 (2014).

22 Ibid.

23 Roman Andrianto Pangondian, Paulus Insap Santosa, and Eko Nugroho, "Faktor-Faktor Yang Mempengaruhi Kesuksesan Pembelajaran Daring Dalam Revolusi Industri 4.0," in Seminar Nasional Teknologi Komputer \& Sains (SAINTEKS), vol. 1, 2019.

${ }^{24}$ Mhd Isman, "Pembelajaran Moda Dalam Jaringan (Moda Daring)" (2016).
} 
membantu Menjaga Perilaku Disiplin. Sama halnya seperti bersekolah, belajar secara daring juga memberikan kesempatan bagi para siswa untuk menjaga perilaku baik melalui interaksi sosial dengan guru maupun teman-temannya. Selain itu, sistem ini juga dapat menjaga sikap bertanggung-jawab ketika diminta mengerjakan tugas-tugas dari guru. ${ }^{25} \mathrm{Hal}$ itu diharapkan dapat menghindari anak dari sikap malas dan acuh tak acuh selama pendemi penjang berlangsung.

Ketiga, manfaat dari pembelajaran daring menjaga otak tetap berkembang. Dengan bersekolah secara daring, siswa akan melatih otaknya serta optimal dan terarah setiap hari serta tetap produktif menciptakan akar-akar disel otak sehingga intelegensi siswa tetap berkembang sesuai dengan umurnya. ${ }^{26}$ Keempat manfaatnya Menjaga Rutinitas Siswa Tetap Terjaga. Sama halnya dengan disiplin, siswa memiliki jadwal atau rutinitas mereka setiap hari seperti waktu belajar, bermain, tidur, makan, memakai seragam dan sebagainya. Belajar daring hadir untuk membantu siswa menjaga rutinitas tersebut tetap berjalan dengan semestinya. Kelima, melatih kemampuan motorik dan koordinasi belajar daring juga bisa meningkatkan kemampuan motorik halus dan kasar pada anak melalui aktivitas menulis dan permainan seperti menuang air dan menyusun stik es krim. Selain itu, anak juga melatih koordinasi mata seperti membaca dan melihat instruksi guru untuk ditiru. ${ }^{27}$

\section{Kelebihan Dan Kekurangan Metode Pembelajaran Daring}

Setiap pembelajaran baik konvensional maupun daring, memiliki kelebihan dan kekurangannya masih-masing. Adapun sisi kelebihan dari pembelajaran daring Waktu dan tempat lebih efektif. Dampaknya siswa \& guru bisa langsung mengikuti proses belajar mengajar dari rumah atau dimanapun. Kemudian Siswa tidak hanya bergantung pada guru, tetapi juga bisa belajar untuk melakukan riset sendiri melalui internet. Selain itu secara tomatis siswa dilatih untuk lebih menguasai teknologi informasi yang terus berkembang. Pembelajaran daring juga menumbuhkan kesadaran pada siswa bahwa gawai bisa digunakan untuk hal-hal yang lebih produktif dan mencerdaskan, tidak hanya untuk bermain sosial media dan game. ${ }^{28}$

Namun disamping itu sisi dari kekurangan pembelajaran daring juga ada. Diantaranya sulit untuk mengontrol mana siswa yang serius mengikuti pelajaran dan mana yang tidak serius. Pembelajaran lebih banyak bersifat teoritis dan minim praktik karena tidak dimungkinkan adanya interaksi langsung dengan siswa. Kekurangan lain adalah bagi mereka yang tinggal dilokasi yang insfrastruktur komunikasinya masih kurang baik tentu akan mengalami kesulitan mengakses internet. Kekurangan lain tidak semua siswa memiliki dan mampu mengakses perlatan teknologi dibutuhkan seperti, laptop, komputer, atau gawail lainnya untuk

${ }^{25}$ Dede Salim Nahdi and Mohamad Gilar Jatisunda, “Analisis Literasi Digital Calon Guru SD Dalam Pembelajaran Berbasis Virtual Classroom Di Masa Pandemi Covid-19,” Jurnal Cakrawala Pendas 6, no. 2 (2020): $116-123$.

${ }^{26}$ Ibid.

${ }^{27}$ Diah Puspita Andini et al., "Peningkatan Motorik Kasar Melalui Pembelajaran Daring Berbasis Whats App," Efektor 8, no. 1 (2021): 89-97.

28 Thityn Ayu Nengrum, Najamuddin Pettasolong, and Muhammad Nuriman, "Kelebihan Dan Kekurangan Pembelajaran Luring Dan Daring Dalam Pencapaian Kompetensi Dasar Kurikulum Bahasa Arab Di Madrasah Ibtidaiyah 2 Kabupaten Gorontalo,” Jurnal Pendidikan 30, no. 1 (2021): 1-12. 
pembelajaran online. Kemudian kelemahan pembelajaran lain terlalu banyak distraksi yang bisa mengganggu konsentrasi siswa saat belajar. ${ }^{29}$

\section{Pengertian Ketuntasan Belajar Menurut Permendikbud}

Ketuntasan Belajar adalah tingkat minimal pencapaian kompetensi sikap, pengetahuan, dan keterampilan meliputi ketuntasan penguasaan substansi dan ketuntasan belajar dalam konteks kurun waktu belajar. ${ }^{30}$ Ketuntasan belajar yang meliputi kurun waktu belajar, meliputi kurun waktu triwulan atau semester, dimana kurikulum yang sudah ditetapkan dalam satu triwulan atau semester, harus diselesaikan. Jadi yang menjadi indikator ketuntasan belajar adalah kurikulum. Apakah jumlah mata pelajaran yang menurut kurikulum dapat diselesaikan dalam waktu satu semester atau tidak. Ketuntasan belajar terdiri atas ketuntasan penguasaan substansi dan ketuntasan belajar dalam konteks kurun waktu belajar. Ketuntasan penguasaan substansi yaitu ketuntasan belajar yang merupakan tingkat penguasaan peserta didik atas mata pelajaran tertentu pada tingkat penguasaan minimal atau di atasnya, sedangkan ketuntasan belajar dalam konteks kurun waktu belajar terdiri atas ketuntasan dalam setiap semester, setiap tahun ajaran, dan tingkat satuan pendidikan. ${ }^{31}$ Ketuntasan belajar dalam satu semester adalah keberhasilan peserta didik menguasai kompetensi dari sejumlah mata pelajaran yang diikutinya dalam satu semester. Ketuntasan Belajar dalam setiap tahun ajaran adalah keberhasilan peserta didik pada semester ganjil dan genap dalam satu tahun ajaran.

Ketuntasan dalam tingkat satuan pendidikan adalah keberhasilan peserta didik menguasai kompetensi seluruh mata pelajaran dalam suatu satuan pendidikan untuk menentukan kelulusan peserta didik dari satuan pendidikan. Jika dilihat dari sejarahnya, konsep pembelajaran tuntas (mastery learning) sebagai suatu model pembelajaran pada tingkat satuan pendidikan dapat dilihat dari dua periode yang berbeda. Periode pertama disebut periode Bloom (1968-1971) karena pada saat itu konsep mastery learning lebih banyak didominasi oleh tulisan-tulisan Bloom di Universitas Chicago. Periode kedua disebut periode Post- Bloom (1971 sampai sekarang) karena pada saat tersebut konsep mastery learning didominasi oleh tulisan-tulisan para murid dan kolega Bloom. Periode Bloom Mastery learning merupakan suatu ide/gagasan yang sudah lama muncul, namun menurut Block (1971) secara periodisasi mengalami banyak penyempurnaan untuk mengatasi berbagai kekurangan atau kelemahan dalam prakteknya yaitu dengan menggunakan teknologi. Bloom merupakan orang pertama menentukan teori dan praktek mastery learning yang berbasis pada teknologi. Teori Bloom ini memberikan kontribusi dalam evolusi konsep mastery 2 learning dari model pembelajaran yang dikembangkan oleh Carroll menjadi model kerja mastery learning.

${ }^{29}$ Andri Anugrahana, "Hambatan, Solusi Dan Harapan: Pembelajaran Daring Selama Masa Pandemi Covid-19 Oleh Guru Sekolah Dasar,” Scholaria: Jurnal Pendidikan dan Kebudayaan 10, no. 3 (2020): 282-289.

${ }^{30}$ Republik Indonesia, "Permendikbud No. 104 Tahun 2014 Tentang Penilaian Hasil Belajar Oleh Pendidik Pada Pendidikan Dasar Dan Pendidikan Menengah,” Jakarta: Kemendikbud (2014).

31 "KETUNTASAN BELAJAR MENURUT PERMENDIKBUD NOMOR 104 TAHUN 2014 - AlMaududy." 


\section{Faktor-Faktor yang Mempengaruhi Ketuntasan Belajar}

Kualitas pendidikan dipengaruhi oleh tiga komponen, yaitu masukan, proses dan keluaran. Komponen-komponen tersebut saling berhubungan, terkait dan saling mendukung untuk mencapai tujuan pendidikan. ${ }^{32}$ Ketuntasan belajar peserta didik merupakan komponen keluaran yang diperoleh dari hasil suatu proses pembelajaran. Ketuntasan belajar yang harus dicapai peserta didik per mata pelajaran dalam Kurikulum Berbasis Kompetensi (KBK), dikenal dengan sebutan Standar Ketuntasan Belajar Minimal (SKBM). Ketuntasan belajar tersebut dapat dilihat dengan menggunakan parameter prestasi belajar siswa dengan melihat nilai kognitif, karena aspek ini dinilai guru untuk melihat penguasaan pengetahuan sebagai ukuran pencapaian hasil belajar siswa. ${ }^{33}$

Ketuntasan belajar peserta didik dipengaruhi oleh beberapa faktor-faktor tersebut terdiri atas komponen-komponen masukan dalam pendidikan itu sendiri. Ssecara garis besar faktorfaktor yang mempengaruhi belajar peserta didik dapat digolongkan menjadi 2, yaitu faktor intern dan faktor ekstern. Faktor intern adalah faktor yang ada dalam diri peserta didik, diantaranya motivasi, sedangkan faktor yang mempengaruhi Ketuntasan Belajar yang datang dari luar peserta didik, diantaranya adalah metode pembelajaran, lingkungan keluarga dan lingkungan sekolah. ${ }^{34}$

Menurut Kotten guru merupakan satu-satunya komponen yang dapat merubah komponen-komponen lainnya. Seorang guru harus membuat strategi pembelajaran yang efektif. Strategi pembelajaran yang dilaksanakan guru dapat dilihat dari metode pembelajaran yang diterapkannya. ${ }^{35}$ metode pembelajaran juga dapat disebut sebagai alat dari perangkat dan cara dalam melaksanakan strategi belajar mengajar. Lingkungan keluarga juga merupakan faktor yang mempengaruhi ketuntasan belajar peserta didik. Keluarga merupakan lingkungan yang pertama dan utama dalam membentuk kepribadian setiap individu. Oleh karena itu keluarga adalah lingkungan pertama dan utama, karena sebelum manusia mengenal sekolah atau lembaga pendidikan yang lain, lingkungan inilah yang pertama ada, dan keluarga disebut lingkungan yang utama karena di dalam lingkungan ini segenap potensi yang dimiliki manusia terbentuk dan sebagian dikembangkan. ${ }^{36}$ Lingkungan keluarga sangat berpengaruh terhadap proses belajar dan perkembangan potensi peserta didik. Namun pada kenyataannya masih banyak orang tua yang kurang memperhatikan pendidikan anak-anak mereka di rumah. Para orang tua menyerahkan sepenuhnya pendidikan anak-anak mereka pada sekolah. Di lain pihak, lingkungan sekolah tempat peserta didik memperoleh pendidikan kedua, juga dapat mempengaruhi keberhasilan peserta didik dalam mencapai ketuntasan belajar. ${ }^{37}$

\footnotetext{
${ }^{32}$ Muhammad Khafid, "Faktor--Faktor Yang Mempengaruhi Ketuntasan Belajar Akuntansi: Motivasi Belajar Sebagai Variabel Intervening,” Lembaran Ilmu Kependidikan 37, no. 1 (2008).

33 Ibid.

${ }^{34}$ Pangondian, Santosa, and Nugroho, "Faktor-Faktor Yang Mempengaruhi Kesuksesan Pembelajaran Daring Dalam Revolusi Industri 4.0."

${ }^{35}$ Natsir B Kotten, “Upaya Pengembangan Profesionalisme Guru Sekolah Dasar,” Jurnal Ilmu Pendidikan 12, no. 1 (2016).

${ }^{36}$ Selfi Lailiyatul Iftitah and Mardiyana Faridhatul Anawaty, "Peran Orang Tua Dalam Mendampingi Anak Di Rumah Selama Pandemi Covid-19," JCE (Journal of Childhood Education) 4, no. 2 (2020): 71.

${ }^{37}$ Nahriyah Fata, "Lingkungan Yang Dapat Mempengaruhi Tumbuhnya Motivasi Dan Keberhasilan Studi Anak Dan Remaja Dalam Perspektif Sosiologi," in FORUM PAEDAGOGIK, 2014.
} 
Berdasarkan kurikulum 2004 yang dikenal dengan Kurikulum Berbasis Kompetensi (KBK), penilaian hasil belajar peserta didik mengacu pada Penilaian Acuan Patokan (PAP). Oleh karena itu penafsiran hasil belajar selalu dibandingkan dengan Standar Ketuntasan Belajar Minimal (SKBM) yang telah ditetapkan. ${ }^{38}$ SKBM adalah batas minimal kompetensi dasar yang harus dicapai peserta didik dari setiap mata pelajaran. Peserta didik yang telah mencapai standar ketuntasan yang telah ditetapkan dinyatakan tuntas dan diberi pengayaan, sedangkan peserta didik yang belum mencapai standar ketuntasan dinyatakan tidak tuntas dan diberi remedial. Tujuan penetapan SKBM tersebut yaitu: (1) menentukan target kompetensi yang harus dicapai peserta didik. (2) sebagai patokan/dasar/acuan menentukan kompeten atau tidak. Konsep yang diambil untuk dijadikan indikator lingkungan sekolah dalam penelitian ini berasal dari konsep unsur-unsur lingkungan sekolah yang mempengaruhi keberhasilan belajar peserta didik yang meliputi: relasi antara peserta didik dengan guru, relasi antar peserta didik, disiplin sekolah, dan fasilitas sekolah. Keempat indikator tersebut paling tidak dapat mewakili indikatorindikator lainnnya dan dapat dijadikan dasar untuk mengukur pengaruh lingkungan sekolah terhadap ketuntasan belajar siswa. ${ }^{39}$.

Lingkungan sekolah dan lingkungan keluarga merupakan dua komponen masukan lingkungan yang mempengaruhi hasil belajar. Relasi antara guru dengan peserta didik, relasi antar sesama peserta didik, kedisiplinan dan fasilitas belajar yang tersedia di sekolah merupakan faktor lingkungan sekolah yang mempengaruhi proses belajar peserta didik dan pada akhirnya hasil belajarnya pun akan sesuai dengan efektif tidaknya proses belajar tersebut. Oleh karena itu lingkungan sekolah yang kondusif harus diciptakan dan fasilitas sekolah harus memadai agar peserta didik termotivasi untuk melakukan kegiatan belajar, sehingga dapat mencapai ketuntasan belajar yang diharapkan. ${ }^{40}$

Lingkungan keluarga merupakan lingkungan yang lebih dulu mempengaruhi perkembangan diri setiap peserta didik. Keluarga adalah lingkungan pertama dan utama. Pola didikan orang tua yang baik dan suasana keluarga yang harmonis menjadikan keadaan psikologi anak terkontrol. Hal ini akan mendukung proses belajar anak berjalan dengan lancar, tenang, bersemangat untuk belajar dan anak akan merasa diperhatikan. ${ }^{41}$ Pola didikan orang tua dan suasana keluarga belumlah cukup untuk membentuk anak termotivasi dalam belajar, oleh karena itu kebutuhan-kebutuhan anak baik secara fisik yang diperlukan bagi keberlangsungan hidupnya maupun kebutuhan menyangkut fasilitas-fasilitas belajar yang diperlukan harus terpenuhi juga. Dengan adanya lingkungan keluarga yang kondusif tersebut dimungkinkan anak akan lebih termotivasi untuk belajar, sehingga tercapailah ketuntasan belajar yang optimal sesuai harapan. ${ }^{42}$ Dari beberapa hasil penelitian yang telah dilakukan sebelumnya menyebutkan

\footnotetext{
${ }^{38}$ Endang Sri Wahyuningsih, Model Pembelajaran Mastery Learning Upaya Peningkatan Keaktifan Dan Hasil Belajar Siswa (Deepublish, 2020).

${ }^{39}$ Khafid, "Faktor--Faktor Yang Mempengaruhi Ketuntasan Belajar Akuntansi: Motivasi Belajar Sebagai Variabel Intervening."

40 Salim Korompot, Maryam Rahim, and Rahmat Pakaya, "Persepsi Siswa Tentang Faktor Yang Mempengaruhi Minat Belajar,” JAMBURA Guidance and Counseling Journal 1, no. 1 (2020): 40-48.

${ }^{41}$ Umi Chulsum, "Pengaruh Lingkungan Keluarga, Kedisiplinan Siswa, Dan Motivasi Belajar Terhadap Hasil Belajar Ekonomi Siswa Di SMA Negeri 7 Surabaya," Jurnal ekonomi pendidikan dan Kewirausahaan 5 , no. 1 (2017): 5-20.

${ }^{42}$ Khafid, "Faktor--Faktor Yang Mempengaruhi Ketuntasan Belajar Akuntansi: Motivasi Belajar Sebagai Variabel Intervening."
} 
bahwa lingkungan keluarga berpengaruh terhadap keberhasilan belajar anak dengan besar pengaruh yang berbeda-beda.

\section{Pengaruh Metode Pembelajaran Daring Bagi Ketuntasan Belajar}

Hasil belajar kognitif siswa selama Pandemik Covid-19 memperoleh hasil yang sangat baik dan baik. Melalui sistem pendidikan jarak jauh dengan sekumpulan metoda pengajaran dimana terdapat aktivitas pengajaran yang dilaksanakan secara terpisah dari aktivitas belajar. Pembelajaran daring diselenggarakan melalui jejaring internet, artinya bahwa penggunaan pembelajaran daring melibatkan unsur teknologi sebagai sarana dan jaringan internet sebagai sistem. ${ }^{43}$ Pembelajaran daring telah banyak dilakukan dalam berbagai tingkatan Pendidikan mulai dari Sekolah Dasar sampai Perguruan Tinggi, terbukti dari beberapa penelitian yang menjelaskan hal tersebut pembelajaran daring memberikan manfaat dalam membantu menyediakan akses belajar bagi semua orang, sehingga menghapus hambatan secara fisik sebagai faktor untuk belajar dalam ruang lingkup kelas, bahkan hal tersebut dipandang sebagai sesuatu yang efektif untuk diterapkan. Akan tetapi tidak bisa dipungkiri bahwa tidak semua pembelajaran dapat dipindahkan ke dalam lingkungan pembelajaran secara online.

Pandemi Covid-19 menjadi persoalan multidimensi yang dihadapi dunia, hal tersebut juga dirasakan dampaknya dalam sektor pendidikan yang menyebabkan penurunan kualitas belajar pada peserta didik. ${ }^{44}$ Masa darurat pandemi ini mengharuskan sistem pembelajaran diganti dengan pembelajaran daring agar proses pembelajaran tetap berlangsung, hal ini jelas mengubah pola pembelajaran yang mengharuskan guru dan pengembang pendidikan, untuk menyediakan bahan pembelajaran dan mengajar siswa secara langsung melalui alat digital jarak jauh. Proses pembelajaran harus tetap dilakukan pada setiap pendidikan formal. Hanya teknologilah yang menjadi jembatan dalam transfer ilmu pengetahuan dari dosen ke mahasiswa. 45

\section{Kesimpulan}

Pandemi Covid-19 yang melanda seluruh dunia telah menciptkan perubahan mobilitas masyarakat global secara drastis. Salah satu bentuk dari perubahan mobilitas itu diantaranya sektor pendidika. Semenjak Covid-19 mewabah di berbagai negara, maka bentuk Pendidikan yang awalnya secara tata muka kini dilakukan secara daring. Pembelajaran daring adalah pembelajaran yang dilakukan dengan perangkat utama menggunakan internet dan smarphone. Dengan majunya teknologi, maka pembelajaran daring mengambil peran penting dalam keberlangsungan pembelajaran. Dengan pembelajaran daring, tentu dirasa banyak manfaatnya. Belajar secara daring akan memberi siswa kendali penuh atas pembelajaran mereka dan siswa dapat bekerja dengan kecepatan mereka sendiri. Temuan kajian ini mengemukakan bahwa

${ }^{43}$ Albitar Septian Syarifudin, "Impelementasi Pembelajaran Daring Untuk Meningkatkan Mutu Pendidikan Sebagai Dampak Diterapkannya Social Distancing," Jurnal Pendidikan Bahasa Dan Sastra Indonesia Metalingua 5, no. 1 (2020): 31-34.

${ }^{44}$ Tampilen Tampilen and Sri Kunarsih, "Peningkatan Kualitas Pendidikan Dalam Masa Pandemi Lewat Pembelajaran Online,” Genta Mulia: Jurnal Ilmiah Pendidikan 12, no. 2 (2021).

${ }^{45}$ Unik Hanifah Salsabila et al., "Peran Teknologi Dalam Pembelajaran Di Masa Pandemi Covid-19," AlMutharahah: Jurnal Penelitian Dan Kajian Sosial Keagamaan 17, no. 2 (2020): 188-198. 
ketuntasan belajar dalam Permendikbud adalah tingkat minimal pencapaian kompetensi sikap, pengetahuan, dan keterampilan meliputi ketuntasan penguasaan substansi dan ketuntasan belajar dalam konteks kurun waktu belajar. Akan tetapi factor mensukseskan ketuntasan belajar ini juga tak lepas dari pengaruh tiga komponen, yaitu masukan, proses dan keluaran. Itu semua dapat dicapai bila orang tua, guru dan lingkungan bersinergi untuk mendongkrak gairah peserta didik dalam pembelajaran.

\section{Referensi}

Andini, Diah Puspita, Marlinah Marlinah, Nurchahyani Nurchahyani, Sesiyana Apriyanti, Esnirani Silaban, And Irma Yuliantina. "Peningkatan Motorik Kasar Melalui Pembelajaran Daring Berbasis Whats App." Efektor 8, No. 1 (2021): 89-97.

Anitah, Sri, And Others. "Strategi Pembelajaran." Jakarta: Universitas Terbuka (2007).

Anugrahana, Andri. "Hambatan, Solusi Dan Harapan: Pembelajaran Daring Selama Masa Pandemi Covid-19 Oleh Guru Sekolah Dasar." Scholaria: Jurnal Pendidikan Dan Kebudayaan 10, No. 3 (2020): 282-289.

Asmuni, Asmuni. "Problematika Pembelajaran Daring Di Masa Pandemi Covid-19 Dan Solusi Pemecahannya." Jurnal Paedagogy 7, No. 4 (2020): 281-288.

Atsani, K H Lalu Gede Muhammad Zainuddin. "Transformasi Media Pembelajaran Pada Masa Pandemi COVID-19.” Al-Hikmah: Jurnal Studi Islam 1, No. 1 (2020): 82-93.

Chulsum, Umi. "Pengaruh Lingkungan Keluarga, Kedisiplinan Siswa, Dan Motivasi Belajar Terhadap Hasil Belajar Ekonomi Siswa Di SMA Negeri 7 Surabaya.” Jurnal Ekonomi Pendidikan Dan Kewirausahaan 5, No. 1 (2017): 5-20.

Fata, Nahriyah. "Lingkungan Yang Dapat Mempengaruhi Tumbuhnya Motivasi Dan Keberhasilan Studi Anak Dan Remaja Dalam Perspektif Sosiologi." In FORUM PAEDAGOGIK, 2014.

Ginting, Abdurrahman. "Esensi Praktis Belajar Dan Pembelajaran (Bandung)." Humaniora 42 (2008).

Hamiyah, Nur, And Muhammad Jauhar. "Strategi Belajar Mengajar Di Kelas." Jakarta: Prestasi Pustaka 294 (2014).

Huatama, Victor Angsono, And Talizaro Tafonao. "Strategi Pemulihan Psikologi Jemaat Pasca COVID-19 Berdasarkan Kitab Mazmur 55." CHARISTHEO: Jurnal Teologi Dan Pendidikan Agama Kristen 1, No. 1 (2021): 1-17.

Iftitah, Selfi Lailiyatul, And Mardiyana Faridhatul Anawaty. "Peran Orang Tua Dalam Mendampingi Anak Di Rumah Selama Pandemi Covid-19." JCE (Journal Of Childhood Education) 4, No. 2 (2020): 71.

Indonesia, Republik. "Permendikbud No. 104 Tahun 2014 Tentang Penilaian Hasil Belajar Oleh Pendidik Pada Pendidikan Dasar Dan Pendidikan Menengah." Jakarta: Kemendikbud (2014).

Iskandarwassid, Dadang Sunendar, And Others. "Strategi Pembelajaran Bahasa." Bandung: PT. Remaja Rosdakarya (2008).

Isman, Mhd. "Pembelajaran Moda Dalam Jaringan (Moda Daring)" (2016).

Karo, Marni Br. "Perilaku Hidup Bersih Dan Sehat (PHBS) Strategi Pencegahan Penyebaran 
Virus Covid-19.” Prosiding Seminar Nasional Hardiknas 1, No. 1 (2020): 1-4.

Khafid, Muhammad. "Faktor--Faktor Yang Mempengaruhi Ketuntasan Belajar Akuntansi:

Motivasi Belajar Sebagai Variabel Intervening." Lembaran Ilmu Kependidikan 37, No. 1 (2008).

Komalasari, Kokom. "Pembelajaran Kontekstual: Konsep Dan Aplikasi” (2017).

Korompot, Salim, Maryam Rahim, And Rahmat Pakaya. "Persepsi Siswa Tentang Faktor Yang

Mempengaruhi Minat Belajar." JAMBURA Guidance And Counseling Journal 1, No. 1 (2020): 40-48.

Kotten, Natsir B. "Upaya Pengembangan Profesionalisme Guru Sekolah Dasar." Jurnal Ilmu Pendidikan 12, No. 1 (2016).

Maman Abdurahman, Sambas Ali Muhidin, Ating Somantri. Dasar-Dasar Metode Statistika Untuk Penelitian. Bandung: CV Pustaka Setia, 2011.

Nahdi, Dede Salim, And Mohamad Gilar Jatisunda. "Analisis Literasi Digital Calon Guru SD

Dalam Pembelajaran Berbasis Virtual Classroom Di Masa Pandemi Covid-19." Jurnal

Cakrawala Pendas 6, No. 2 (2020): 116-123.

Nengrum, Thityn Ayu, Najamuddin Pettasolong, And Muhammad Nuriman. "Kelebihan Dan

Kekurangan Pembelajaran Luring Dan Daring Dalam Pencapaian Kompetensi Dasar

Kurikulum Bahasa Arab Di Madrasah Ibtidaiyah 2 Kabupaten Gorontalo." Jurnal

Pendidikan 30, No. 1 (2021): 1-12.

Pangondian, Roman Andrianto, Paulus Insap Santosa, And Eko Nugroho. "Faktor-Faktor Yang

Mempengaruhi Kesuksesan Pembelajaran Daring Dalam Revolusi Industri 4.0." In

Seminar Nasional Teknologi Komputer \& Sains (SAINTEKS). Vol. 1, 2019.

Permadi, Putu Lantika, And I Made Sudirga. "Problematika Penerapan Sistem Karantina

Wilayah Dan PSBB Dalam Penanggulangan Covid-19.” Jurnal Kertha Semaya 8, No. 9 (2020): 1355-1365.

Prasetya, Joko Tri, And Abu Ahmadi. "Strategi Belajar Mengajar." Bandung: CV (2005).

Sahensolar, Sandra Christina, And Simon Simon. "Respon Teologis Terhadap Dampak Pandemik Coronaviruses Disease 2019." Manna Rafflesia 8, No. 1 (2021): 176-195.

Salsabila, Unik Hanifah, Lailli Irna Sari, Khusna Haibati Lathif, Ayu Puji Lestari, And Asyharinur Ayuning. "Peran Teknologi Dalam Pembelajaran Di Masa Pandemi Covid19.” Al-Mutharahah: Jurnal Penelitian Dan Kajian Sosial Keagamaan 17, No. 2 (2020): $188-198$.

Saptono, Yohanes Joko. "Motivasi Dan Keberhasilan Belajar Siswa." REGULA FIDEI: Jurnal Pendidikan Agama Kristen 1, No. 1 (2016): 181-204.

Saputro, Arnaz Anggoro, Yudi Dwi Saputra, And Guntum Budi Prasetyo. "Analisis Dampak Covid-19 Terhadap Kesadaran Masyarakat Dalam Penerapan Protokol Kesehatan." Jurnal Porkes 3, No. 2 (2020): 81-92.

Sari, Widya, Andi Muhammad Rifki, And Mila Karmila. "Analisis Kebijakan Pendidikan Terkait Implementasi Pembelajaran Jarak Jauh Pada Masa Darurat Covid 19.” Jurnal Mappesona 2, No. 2 (2020).

Simbolon, Naeklan. "Faktor-Faktor Yang Mempengaruhi Minat Belajar Peserta Didik." Elementary School Journal Pgsd Fip Unimed 1, No. 2 (2014).

Simon, Simon, Alfons Renaldo Tampenawas, Joko Santoso, Astrid Maryam Yvonny Nainupu, 
Semuel Ruddy Angkouw, And Alvonce Poluan. "Participation Of Religious Leaders In Helping The Success Of The Government's COVID-19 Vaccination Program." Evangelikal: Jurnal Teologi Injili Dan Pembinaan Warga Jemaat 5, No. 2 (2021): 234245.

Sutikno, Sobry. "Pemimpin Dan Kepemimpinan.” Lombok: Holistica (2014).

Syarifudin, Albitar Septian. "Impelementasi Pembelajaran Daring Untuk Meningkatkan Mutu Pendidikan Sebagai Dampak Diterapkannya Social Distancing." Jurnal Pendidikan Bahasa Dan Sastra Indonesia Metalingua 5, No. 1 (2020): 31-34.

Tampilen, Tampilen, And Sri Kunarsih. "Peningkatan Kualitas Pendidikan Dalam Masa Pandemi Lewat Pembelajaran Online." Genta Mulia: Jurnal Ilmiah Pendidikan 12, No. 2 (2021).

Wahyuningsih, Endang Sri. Model Pembelajaran Mastery Learning Upaya Peningkatan Keaktifan Dan Hasil Belajar Siswa. Deepublish, 2020.

Wulandari, Ayu, And Gusti Ngr Sastra Agustika. "Dramatik Pembelajaran Daring Pada Masa Pandemi Covid-19." Mimbar PGSD Undiksha 8, No. 3 (2020): 515-526.

"Ketuntasan Belajar Menurut Permendikbud Nomor 104 Tahun 2014 - Al-Maududy." 